Volume 118

Issue 1 Dickinson Law Review - Volume 118,

2013-2014

6-1-2013

\title{
Terrorism, Tips, and the Touchstone of Reasonableness: Seeking a Balance Between Threat Response and Privacy Dilution
}

Geoffrey S. Corn

Follow this and additional works at: https://ideas.dickinsonlaw.psu.edu/dlra

\section{Recommended Citation}

Geoffrey S. Corn, Terrorism, Tips, and the Touchstone of Reasonableness: Seeking a Balance Between Threat Response and Privacy Dilution, 118 Dick. L. REV. 129 (2013).

Available at: https://ideas.dickinsonlaw.psu.edu/dlra/vol118/iss1/5

This Article is brought to you for free and open access by the Law Reviews at Dickinson Law IDEAS. It has been accepted for inclusion in Dickinson Law Review by an authorized editor of Dickinson Law IDEAS. For more information, please contactlja10@psu.edu. 


\title{
Terrorism, Tips, and the Touchstone of Reasonableness: Seeking a Balance Between Threat Response and Privacy Dilution
}

\author{
Geoffrey S. Corn*
}

\begin{abstract}
It is the morning of the Oklahoma City terrorist bombing. The phone rings in the Oklahoma City Police Department, and a duty officer answers. The caller says, "There's a Ryder rental truck parked in front of the Murrah Federal Building with a massive bomb inside set to go off within one hour." The caller then hangs up. The duty officer alerts all nearby patrol units, and within three minutes an officer confirms the presence of the Ryder truck. What should the police do next? What response would be reasonable? Does the law permit them to cordon the area, take control of the vehicle, and use bomb detection technology to penetrate into the truck in order to confirm or deny the tip? If so, what limits, if any, apply to the use of contraband they may find inside the truck as evidence in a subsequent trial?
\end{abstract}

\section{Table of Contents}

I. INTRODUCTION

II. AUTOMOBILE SEARCHES, EXISTING STANDARDS OF

REASONABLENESS, AND RISK PREVENTION: AN INHERENT

DISCONNECT.

A. Warrant Exceptions: Close, but not Close Enough

B. The Special Needs Doctrine: Closer, but Maybe Not?

* Presidential Research Professor of Law, South Texas College of Law; Lieutenant Colonel (Retired), U.S. Army Judge Advocate General's Corps. Prior to joining the faculty at South Texas, Professor Corn served in a variety of military assignments, including as the Army's senior law of war advisor, supervisory defense counsel for the Western United States, Chief of International Law for U.S. Army Europe, and as a tactical intelligence officer in Panama. I am especially grateful to my research assistant, Joel Glover, whose dedication was instrumental in bringing this article to fruition. 
C. Anonymous Tips, Existing Facts, and Reasonable Suspicion.

III. NEED AND RESPONSE: SHOULD REASONABLENESS TURN ON EMERGING THREATS?

A. A Terrorism-Specific Test for Reasonable Suspicion? 146

B. Scope: A Logical Expansion 152

IV. PROTECTIONS AGAINST OVER-BREADTH: LIMITING THE USE OF EVIDENCE SEIZED DURING A PROTECTIVE VEHICLE SEARCH.

A. Evidence Exclusion: The Ultimate Subterfuge Deterrent

B. The Military Exclusionary Approach

V.

CONCLUSION 165

\section{INTRODUCTION}

Security experts continue to remind Americans that the threat of terrorist attacks inflicting mass casualties on the homeland is not a question of if, but of when. ${ }^{1}$ This, coupled with the increasing prevalence of the homegrown lone-wolf terrorist-the radicalized terrorist operative within our midst who decides to act on his own to achieve maximum harmful effect-is increasingly viewed as a significant contemporary terrorist threat. ${ }^{2}$ For these potential terrorists, conventional high explosive devices concealed in automobiles are the logical means to achieve their mass casualty objectives. This is unsurprising; attacks such as the Oklahoma City bombing and failed attempts in Times Square and Portland all indicate the effectiveness and relative ease of employment of such weapons. ${ }^{3}$ These incidents illustrate the ideal nature of vehicles to deploy, conceal, and ultimately execute mass casualty attacks. ${ }^{4}$ Indeed, the car bomb has become a weapon of choice around the globe for terrorists who seek to inflict mass casualties with minimal resources, especially in densely populated areas. ${ }^{5}$ The ease of construction and employment, and the difficulty of detection once the

1. See generally Jerome P. BJElopera, CONG. RESEARCH SERV., R41416, AMERICAN JiHADIST TERRORISM: COMBATING A COMPLEX THREAT (2011), available at http://bit.ly/bfRVU6.

2. See Jessica Stern, The Protean Enemy, 82 Foreign AfF. 27, 33-34 (2003).

3. See generally Al Baker \& William K. Rashbaum, Police Find Car Bomb in Times Square, N.Y. TIMES, May 2, 2010, at Al, available at http://nyti.ms/aZdOkA; David Johnston, At Least 31 Are Dead, Scores Are Missing After Car Bomb Attack in Oklahoma City Wrecks 9-Story Federal Office Building, N.Y. TIMES, Apr. 20, 1995, at A1; Oregon Bomb-Plot Suspect Wanted 'Spectacular Show,' USA TODAY (Nov. 28, 2010), http://usat.ly/e3t0qn.

4. See generally Robert Baer, Why the Car Bomb Is a Terrorist's Best Weapon, TIME (Sept. 22, 2008), http://ti.me/5MZOGW.

5. See Vehicle Borne IEDs (VBIEDs) [Car Bombs], GlobalSECURITY.orG, http://bit.ly/166eFNF (last visited Aug. 24, 2013) [hereinafter VBIEDs]. 
vehicle is mixed within normal dense traffic, ${ }^{6}$ indicates why this is logical.

In areas of ongoing combat operations or post-conflict stability operations, military and civilian security personnel utilize extensive random vehicle inspections to detect and deter the car bomb threat. ${ }^{7}$ It is, however, unrealistic to expect this counter-terror tactic to be extended to the domestic U.S. context. It is true that established Fourth Amendment jurisprudence does permit random checkpoint searches to deter the threat of terrorist attacks. ${ }^{8}$ However, widespread domestic use of such random checkpoints to a degree even closely resembling use in conflict zones is almost inconceivable. ${ }^{9}$ Furthermore, in practice these counter-terrorism checkpoints are normally utilized only in response to some credible report of imminent terrorist attacks, which raises another concern: does an anonymous tip qualify as a credible threat indicator? And if so, once police have established individualized suspicion derived from an anonymous tip, and therefore know exactly where to look or whom to look for, is the use of the checkpoint search reasonable? The answer to these questions is unclear. From a practical perspective, the efficacy of this permissible deterrent tactic in response to a lone-wolf threat is also unclear due to the extremely unpredictable nature of the threat. ${ }^{10}$

As in other criminal investigations, terrorism investigations-in particular the investigatory response to the threat of the lone-wolf terrorist-will frequently necessitate heavy reliance on tips from confidential or anonymous informants. Unlike other criminal investigations, however, the nature of the threat presents a risk to the public of an exceedingly high order of magnitude. One need only consider the level of destruction that would have resulted had the Times Square or Portland bombing attempts been consummated. Terrorism investigations thus present a unique dilemma for law enforcement. Like other law enforcement investigations, the use of tips to focus police efforts is highly probable. However, unlike other types of investigations, police will rarely have the luxury of conducting thorough investigations to corroborate the tip sufficiently to establish either probable cause or reasonable suspicion to justify a seizure or search of a suspected car bomb. We must therefore anticipate that in the future, law enforcement

6. Id.

7. See U.S. Dep't of the ARmy, Field Manual 3-19.4: Military Police LEADERS' HANDBOOK 684-87 (2002).

8. See infra notes $51-62$ and accompanying text.

9. See Rachel R. Watson, When Individual Liberty and Police Procedure Collide: The Unconstitutionality of High-Crime Area Checkpoints, 24 U. DAYTON L. REV. 95, 109-11 (1998).

10. See United States v. Tehrani, 49 F.3d 54, 58 (2d Cir. 1995). 
agents will become aware of car bomb threats from informant tips that fail to generate the type of additional information needed to render an immediate responsive seizure or search of the vehicle reasonable within the meaning of existing Fourth Amendment jurisprudence. As a result, the nature of this emerging and genuinely frightening threat, combined with the existing standards defining the reasonableness of searches and seizures, creates a troubling disconnect.

Accordingly, I propose that it is necessary to adjust both the type of information required to establish reasonable suspicion and the scope of the accordant protective search in response to a tip of an imminent terrorist attack endangering the public. This adjustment would allow a finding of reasonable suspicion based on police confirmation of existing and openly available details provided by a car bomb tip. A protective search based on the Terry doctrine would be permitted to extend to any part of the car capable of concealing an explosive device, including the trunk and other concealed interior areas. These adjustments would allow an effective law enforcement response to such a tip and ameliorate the current disconnect between the logical response to a car bomb tip and the existing standards for assessing the reasonableness of a search or seizure-a disconnect exacerbated by terrorists' proclivity to use the car bomb as a weapon of choice to produce mass casualties. ${ }^{11}$

Expanding the authority to search or seize an automobile, however, will also increase the risk of police abuse of individual liberty. Therefore, I also propose that any such expansion of terrorist threat response authority should be offset by a limitation on the admissibility of evidence seized pursuant to the plain view doctrine. ${ }^{12}$ When such evidence is the result of a protective automobile search or seizure conducted in response to an anonymous car bomb tip, failure to validate the terrorist threat as the result of the search (by finding terrorist-related evidence) would trigger a presumption of inadmissibility for any evidence unrelated to the alleged terrorist threat. Admissibility of such evidence would then require that the prosecution establish by clear and convincing evidence that the protective search was in fact legitimate. ${ }^{13}$ This limitation would strike a reasonable balance between the need to search vehicles on a lower quantum of proof in response to nonpredictive tips of terrorist activity with the protection of the individual from the consequence of searches that prove to be based on faulty or fabricated information. ${ }^{14}$ It will also protect society from subterfuge

11. See generally Baer, supra note 4 .

12. See Coolidge v. New Hampshire, 403 U.S. 443, 465-73 (1971).

13. See id.; Terry v. Ohio, 392 U.S. 1,29 (1968).

14. See Florida v. J.L., 529 U.S. 266, 274 (2000); Terry, 392 U.S. at 29. 
searches because police will know that deliberate misuse of this terrorist tip exception will produce no evidentiary benefit. ${ }^{15}$

Part II of this Article will provide an overview of existing standards for assessing the reasonableness of searches or seizures; address dangers associated with the combination of homegrown terrorism and car bombs; and explain how existing tests for reasonableness fail to sufficiently address this threat. Part III will propose a modification of the test for establishing reasonable suspicion and the permissible scope of a reasonable suspicion-based response to a car bomb threat. Part IV will then propose a counterbalance to this expanded search authority: a limited evidentiary use rule derived from the military inspection context. This Article will conclude in Part V.

\section{AUTOMOBILE SEARCHES, EXISTING STANDARDS OF \\ REASONABLENESS, AND RISK PREVENTION: AN INHERENT DISCONNECT}

Existing automobile search authority provides the logical starting point for analyzing this dilemma and considering an appropriate response. ${ }^{16}$ The Fourth Amendment prohibits unreasonable searches and seizures, ${ }^{17}$ and it is an axiom of Fourth Amendment analysis that " $[t]$ he touchstone of the Fourth Amendment is reasonableness." Reasonableness is presumed where police have probable cause that an automobile contains contraband and obtain a warrant to search the automobile. ${ }^{19}$ Such a presumption is difficult to challenge. ${ }^{20}$ However, most automobile searches occur without a warrant. ${ }^{21}$ In such situations, the burden is on the government to assert an established exception to the warrant requirement and thereby rebut the presumptive unreasonableness of the warrantless search. ${ }^{22}$

This burden is often easily satisfied. Well-settled Fourth Amendment jurisprudence permits warrantless searches of automobiles as reasonable pursuant to both the automobile and/or exigent

15. See J.L., 529 U.S. at 274.

16. See Cabbler v. Superintendent, 374 F. Supp. 690, 693-97 (E.D. Va. 1974), rev'd on other grounds, 528 F.2d 1142 (4th Cir. 1975).

17. U.S. CONST. amend. IV ("The right of the people to be secure in their persons, houses, papers, and effects, against unreasonable searches and seizures, shall not be violated. ...").

18. Florida v. Jimeno, 500 U.S. 248, 250 (1991).

19. See United States v. Tamari, 454 F.3d 1259, 1261 (11th Cir. 2006).

20. See id. at 1261-62.

21. See Maryland v. Dyson, 527 U.S. 465, 466-67 (1999).

22. See United States v. Ross, 456 U.S. 798,809 (1982) ("[T]he [automobile] exception to the warrant requirement ... applies only to searches of vehicles that are supported by probable cause."). 
circumstances exceptions. ${ }^{23}$ However, both of these exceptions apply only to the warrant requirement and presuppose that the search is conducted pursuant to valid probable cause. Therefore, neither exception alters the conclusion that a full search of a car based on a tip that does not provide probable cause would be unreasonable. ${ }^{24}$ Accordingly, the existence of valid probable cause remains the touchstone to determine whether a full evidentiary search of the vehicle is reasonable. ${ }^{25}$

\section{A. Warrant Exceptions: Close, but not Close Enough}

Since the Supreme Court decided Carroll v. United States ${ }^{26}$ in 1925, automobiles have been exempt from the normal warrant requirement. The Carroll exception provides that where police have probable cause that contraband or evidence is in an automobile (or in a container inside an automobile), a search for that item is reasonable without a warrant. ${ }^{27}$ Accordingly, if police observation of an automobile establishes probable cause that the automobile contains a car bomb, immediate action to search the automobile for the car bomb (or to seize the automobile to remove it from the scene) would be reasonable, and any contraband or evidence that comes into plain view during that search would be admissible for later use at trial. It would matter not whether the police observation resulting in probable cause occurred in response to an anonymous $\operatorname{tip}^{28}$ - such as the discovery of the car bomb by the New York Police Department on New Year's Eve 2010 in response to a tip from a street vendor ${ }^{29}$-or was merely random. So long as the information resulting in probable cause was not obtained as the result of an unreasonable search or seizure, a full search of the automobile is reasonable. ${ }^{30}$

Exigent circumstances would also permit a full search of the automobile based on probable cause that it had been weaponized, although the automobile exception to the warrant requirement renders

23. See infra notes $26-34$ and accompanying text.

24. Michigan v. Long, 463 U.S. 1032, 1050 (1983) (discussing how an officer conducting an otherwise lawful search of an automobile "clearly cannot be required to ignore [other] contraband" because "the Fourth Amendment does not require its suppression in such circumstances").

25. See id. at 1049-50 (reasoning that the protection of self and others authorizes police officers to conduct investigatory searches).

26. Carroll v. United States, 267 U.S. 132 (1925).

27. See id. at 156-57 ("In cases where seizure is impossible except without warrant, the seizing officer acts unlawfully and at his peril unless he can show the court probable cause.").

28. See Alabama v. White, 496 U.S. 325, 329 (1990).

29. See generally Baker \& Rashbaum, supra note 3 .

30. See Illinois v. Gates, 462 U.S. 213, 245-46 (1983). 
this exception functionally superfluous. ${ }^{31}$ Because the exigent circumstances exception is based in part on an underlying safety rationale, it is tempting to conclude that it should justify a search in response to the anonymous tip that forms the hypothetical context for this discussion. ${ }^{32}$ However, exigent circumstances arise in response to situations that by their very nature create probable cause. ${ }^{33}$ Thus, like the automobile exception, the exigent circumstances exception presupposes the existence of probable cause-the cause that itself triggers the exigency justifies dispensing with the warrant requirement. ${ }^{34}$ Indeed, as the Court has noted, this exception is in effect an efficiency compromise: when police confront an exigency, it would be inefficient and potentially dangerous to require them to obtain a warrant prior to responding to the exigency. ${ }^{35}$ Accordingly, as an exception only to the warrant requirement, exigent circumstances will not justify a search based on anything less than probable cause. ${ }^{36}$

Accordingly, because both the automobile exception and the exigency exception apply only to the warrant requirement, probable cause remains a necessary predicate for the reasonable search of an automobile and seizure of contraband or evidence discovered therein. ${ }^{37}$ Whether verification of the description and location of a vehicle provided by an anonymous tip would establish probable cause is therefore a critical question. If the answer is yes, a fully intrusive response is reasonable, and any evidence uncovered during the search of the vehicle, even if unrelated to the terrorist tip and investigation, would be admissible pursuant to the plain view doctrine. ${ }^{38}$ If the answer is no, the full-blown search of the vehicle would be unreasonable, and evidence uncovered would be inadmissible as the fruit of that unreasonable search. However, the issue of seizure is slightly more complicated and will be addressed below.

31. See Mincey v. Arizona, 437 U.S. 385, 392-93 (1978).

32. See Warden, Md. Penitentiary v. Hayden, 387 U.S. 294, 298 (1967).

33. See Jeff Fisher, Lowering Standards: The Simultaneous-School-Bombing-andShooting-Threat Exception of Armijo Ex Rel. Armijo Sanchez v. Peterson, 41 N.M. L. REV. 69, 85-86 (2011).

34. See Hayden, 387 U.S. at 300-10; see, e.g., J. Keith Killian, Warrantless Automobile Searches and Seizure: The Chambers Immobilization Doctrine and Its Abandonment in Colorado, 50 U. CoLO. L. REv. 75, 77-79 (1978).

35. See Hayden, 387 U.S. at 309-10; Gerald G. Ashdown, Good Faith, the Exclusionary Remedy, and Rule-Oriented Adjudication in the Criminal Process, 24 WM. \& MARY L. REV. 335, 354-55 (1983).

36. See Adam Kennedy Peck, The Securing of the Premises Exception: A Search for the Proper Balance, 38 VAND. L. REV. 1589, 1618-19 (1985).

37. California v. Acevedo, 500 U.S. 565, 569 (1991).

38. See Horton v. California, 496 U.S. 128, 141 (1990) ("[T] he seizure of an object in plain view does not involve an intrusion on privacy."). 
Existing probable cause jurisprudence almost conclusively indicates that verifying open and non-predictive information such as the location and characteristics of the vehicle referenced in the tip is insufficient to establish probable cause. The seminal decision Illinois v. Gates ${ }^{39}$ provides the longstanding and controlling framework for assessing when an informant's tip creates probable cause. ${ }^{40}$ While the Supreme Court in Gates rejected a rigid analytical framework and adopted a totality of the circumstances approach, it nonetheless indicated the continuing relevance of assessing tips through a two-prong lens: (1) the veracity of the informant; and (2) the foundation for the tip. ${ }^{41}$ The veracity prong focuses on whether there is some way to establish that the tipster's information is trustworthy -in effect some substitute for oath or affirmation; ${ }^{42}$ the foundation prong focuses on how the tipster came to know of the criminal conduct identified in the tip. ${ }^{43}$ The totality of the circumstances test indicates that probable cause may exist in situations in which the strength of one of these prongs is slight, so long as the strength of the other prong offsets this deficiency. ${ }^{44}$ For example, in Gates, the Court concluded that it was virtually impossible to know anything about the veracity of an anonymous informant, as opposed to a confidential informant with a track record. ${ }^{45}$ As a result, police corroboration of the tip's detailed predictions about the defendants' future conduct, which the Court concluded would only be known to someone with intimate knowledge of the defendants' activities, provided a solid foundation rendering the overall reliability of the tip sufficient to establish probable cause. ${ }^{46}$

Accordingly, Gates provides several important guideposts for assessing the sufficiency of a tip when determining whether probable cause exists. For one, anonymous tips, because they provide virtually no indicia of veracity, must be based on a solid foundation of knowledge to

39. Illinois v. Gates, 462 U.S. 213 (1983).

40. Id. at 244-45 ("It is enough, for purposes of assessing probable cause, that corroboration through other sources of information reduced the chances of a reckless or prevaricating tale, thus providing a substantial basis for crediting the hearsay.") (internal quotation marks omitted).

41. See id. at $241-45$.

42. See id. at $243-44$.

43. See $i d$. at $241-42$.

44. See Gates, 462 U.S. at 238 ("The task of the issuing magistrate is simply to make a practical, common-sense decision whether, given all the circumstances set forth in the affidavit before him ... there is a fair probability that contraband or evidence of a crime will be found in a particular place.").

45. Id. at 237.

46. Id. at 245 ("If the informant had access to accurate information of this [predictive] type a magistrate could properly conclude that it was not unlikely that he also had access to reliable information of the ... alleged illegal activities."). 
compensate for this deficiency. ${ }^{47}$ In addition, when assessing the quality of this foundation, there are two key considerations. First, is the tip predictive in nature? Second, do the predictions suggest the informant's knowledge is the result of an intimate connection with or inside access to the activities of the target? If subsequent police investigation indicates that the answer to these questions is yes-investigation that corroborates that the tipster is providing predictive insider information-then the anonymity of the tip is sufficiently offset and probable cause is established. ${ }^{48}$ In a situation involving an anonymous tip of terrorist activity, it would be extremely unlikely that police investigation could validate such a solid foundation for the tip (which may not be based on the ultimate discovery of a bomb in the car precisely because this is the suspicion that must be validated prior to a search that results in this discovery). When police corroboration is impracticable or impossiblethe situation that would arise as the result of an anonymous tip of a terrorist car bomb-what alternate options might apply?

This probable cause requirement is triggered only when gathering evidence is the primary purpose of the investigatory response. Responding to such a tip, however, implicates an interest quite distinct from simply gathering evidence for the purpose of building a case: that of protecting the police and the public from imminent harm. Because of this reality, probable cause is not the exclusive test of reasonableness pursuant to the Fourth Amendment. ${ }^{49}$ This situation implicates two alternative theories of reasonableness. The first is the special needs doctrine, ${ }^{50}$ which allows police to conduct carefully limited searches or seizures without warrant or even reasonable suspicion when the primary purpose of the intrusion is protection of the public from an imminent threat.

\section{B. The Special Needs Doctrine: Closer, but Maybe Not?}

A tip of an impending terrorist attack utilizing a car bomb unquestionably implicates vital public safety interests. As a result, the special needs doctrine is the most logical exception to the normal Fourth

47. See id. at 234-35.

48. See id. at $245-46$.

49. See infra note 53 and accompanying text.

50. See Mich. Dep't of State Police v. Sitz, 496 U.S. 444, 449-50 (1990) ("[W]here a Fourth Amendment intrusion serves special governmental needs, beyond the normal need for law enforcement, it is necessary to balance the individual's privacy expectations against the Government's interests to determine whether it is impractical to require a warrant or some level of individualized suspicion in the particular context." (quoting Treasury Emps. v. Von Raab, 489 U.S. 656, 665-66 (1989))); see also MacWade v. Kelly, 460 F.3d 260, 269-75 (2d Cir. 2006). 
Amendment warrant and probable cause requirement that might justify a seizure and/or search of the target vehicle in response to an anonymous tip. ${ }^{51}$ This doctrine permits the government to use checkpoint searches and other brief and limited investigatory intrusions absent any individualized suspicion. ${ }^{52}$ The primary purpose of a special needs search must be the protection of the public, and not the collection of evidence. $^{53}$ This might seem like an exception that swallows the rule, but it is not. The Supreme Court has been relatively vigilant in gatekeeping by rejecting asserted public safety justifications when it appears the special needs search was utilized as a subterfuge to avoid the burden of establishing individualized suspicion in order to search for evidence of criminal misconduct. ${ }^{54}$ The Supreme Court has, however, indicated that this exception would be applicable to checkpoint searches in response to a credible threat of imminent terrorist attack. ${ }^{55}$ Such use was subsequently held lawful in MacWade $v$. Kelly, ${ }^{56}$ where the Second Circuit Court of Appeals upheld random checkpoint searches of subway patrons in New York City in response to a concern that the United States

51. See Ferguson v. City of Charleston, 532 U.S. 67, 73-75 (2001). The Court stated:

The term "special needs" first appeared in Justice Blackmun's opinion concurring in the judgment in New Jersey v. T.L.O., 469 U.S. 325, 351 (1985). In his concurrence, Justice Blackmun agreed with the Court that there are limited exceptions to the probable-cause requirement, in which reasonableness is determined by "a careful balancing of governmental and private interests," but concluded that such a test should only be applied "in those exceptional circumstances in which special needs, beyond the normal need for law enforcement, make the warrant and probable-cause requirement impracticable ...." Ibid. This Court subsequently adopted the "special needs" terminology in $O^{\prime}$ Connor v. Ortega, 480 U.S. 709, 720 (1987) (plurality opinion), and Griffin v. Wisconsin, 483 U.S. 868, 873 (1987), concluding that, in limited circumstances, a search unsupported by either warrant or probable cause can be constitutional when "special needs" other than the normal need for law enforcement provide sufficient justification. See also Vernonia School Dist. $47 J$ v. Acton, 515 U.S. 646, 652-53 (1995).

Id. at 74 n. 7 ; see also Neumeyer v. Beard, 421 F.3d 210, 214 (3d Cir. 2005).

52. Neumeyer, 421 F.3d at 214 ("Under this standard, the constitutionality of a particular search 'is judged by balancing its intrusion on the individual's Fourth Amendment interests against its promotion of legitimate government interests' beyond that of typical law enforcement." (quoting Wilcher v. City of Wilmington, 139 F.3d 366, 373-74 (3d Cir. 1998))).

53. Ronald M. Gould \& Simon Stem, Catastrophic Threats and the Fourth Amendment, 77 S. CAL. L. REv. 777, 813-15 (2004).

54. City of Indianapolis v. Edmond, 531 U.S. 32, 40-42 (2000).

55. See id. at 44 ("The exigencies created by [terrorism] scenarios are far removed from the circumstances under which authorities might simply stop cars as a matter of course to see if there just happens to be a felon leaving the jurisdiction.").

56. MacWade v. Kelly, 460 F.3d 260, 268-69, 275 (2d Cir. 2006). 
would be targeted for a subway attack following the London subway attack. $^{57}$

It is unsurprising that the special needs exception has been invoked in response to threats of terrorist attacks to justify checkpoint searches. The exception arose in response to the Supreme Court's recognition that there are some threats to society that cannot be adequately deterred without deviating from the normal individualized suspicion requirement. $^{58}$ However, it is precisely because this exception allows for random searches that the Court has imposed limits on its use, the most important of which is the primary purpose requirement: the government must establish that responding to a legitimate public safety risk is the primary purpose of the random inspection program. ${ }^{59}$ If, as in New York City, the government is able to identify a credible terrorist car bomb threat, the special needs exception would almost certainly permit the use of random checkpoints to conduct limited searches to deter would-be terrorists and reduce the risk that vehicles entering a certain area were in fact weaponized. ${ }^{60}$

A response to an anonymous car bomb tip would almost certainly fall within a legitimate "primary purpose" of ensuring the safety of police and the public, and not discovery of evidence. ${ }^{61}$ However, it is not clear whether the individualized suspicion established by the tip (although insufficient to establish reasonable suspicion under existing standards) undermines the viability of this exception to the warrant and probable cause requirement. It is clear that a response to such a tip does not involve the type of random intrusion normally associated with application of this exception to counter-terrorist checkpoint searches, such as the random bag checks used to deter terrorist attacks on the New York City subway system. Instead, reaction to a tip indicates some level of individualized suspicion. While the special needs exception has been utilized in response to credible indicators of imminent terrorist attack (which could arguably be provided by the tip), even in these situations there is an absence of individualized suspicion. ${ }^{62}$

Individualized suspicion ultimately may not impact the viability of invoking the special needs doctrine to respond to a car bomb tip. However, it may trigger a derivative requirement to establish reasonable

57. See id.

58. See id. at 271-72.

59. See Gould \& Stern, supra note 53, at 813-15.

60. See MacWade, 460 F.3d at 268-69.

61. Mich. Dep't of State Police v. Sitz, 496 U.S. 444, 454-55 (1990) (holding that checkpoints that, on balance, weigh more heavily in favor of public safety over public intrusion do not constitute an unconstitutional search for evidence).

62. See id. at 454 . 
suspicion to justify a responsive search or seizure even within the special needs context. Indeed, the case considered the "birth" of the special needs doctrine, New Jersey v. T.L.O. ${ }^{63}$ where the Court held that the search of a public school student's purse was reasonable without a warrant or probable cause, suggests just such a requirement. ${ }^{64}$ In T.L.O., the principal clearly had established individualized suspicion. However, the Court did require that the search be supported by what appears to be reasonable suspicion, noting that "[w]here a careful balancing of governmental and private interests suggests that the public interest is best served by a Fourth Amendment standard of reasonableness that stops short of probable cause, we have not hesitated to adopt such a standard. ${ }^{65}$ Thus, T.L.O. seems to indicate that while special needs-a compelling public interest-will justify deviation from the normal warrant and probable cause requirement, if the government official has established individualized suspicion, that suspicion must at least qualify as "reasonable." Later applications of the special needs exception addressed a quite different situation: the absence of any individualized suspicion coupled with a compelling public interest to conduct suspicionless inspections. Indeed, it is the inability to establish individualized suspicion that seems to be a common element of many of the situations falling within the exception, and in many ways creates the special need. ${ }^{66}$

Accordingly, extending the special needs exception to this type of situation is problematic. Unlike in T.L.O., the individualized suspicion created by corroboration of the existing details provided by an anonymous car bomb tip would fail to provide the minimal indicia of reliability necessary to render even a protective Terry-type search reasonable. Thus, application of the exception would allow a search based on what is currently insufficient information to justify the intrusion, and would therefore encourage the type of end run around the substantive requirements of the Fourth Amendment that the Court has guarded against when limiting application of the doctrine. ${ }^{67}$

63. New Jersey v. T.L.O., 469 U.S. 325, 341 (1985).

64. See id.

65. See id. at 341 .

66. Sitz, 496 U.S. at $449-50$.

67. See Ferguson v. City of Charleston, 532 U.S. 67, 68-69 (2001) (holding that drawing the blood of pregnant patients "for the specific purpose of incriminating those patients" for illegal drug use was a violation of the "closely guarded category of [the] special needs" to the Fourth Amendment's exclusionary rule) (internal quotation marks omitted); see also City of Indianapolis v. Edmond, 531 U.S. 32, 47 (2000) ("When law enforcement authorities pursue primarily general crime control purposes at checkpoints... stops can only be justified by some quantum of individualized suspicion."). 
If the existence of individualized suspicion does require the establishment of reasonable suspicion as a predicate for invoking the special needs doctrine in response to an anonymous tip, something more than the tip would be required to render a seizure or search reasonable. ${ }^{68}$ In other words, if the police know where they want to search, the special needs exception may provide an exception to the normal warrant and probable cause requirement, but would not totally eliminate the requirement for establishing at least some objectively verifiable cause. ${ }^{69}$ Thus, for example, if the police receive an anonymous tip of a car bomb location, use of the special needs exception to seize or search that vehicle or others suspected of matching the tip description might not be reasonable even conceding a primary protective purpose. ${ }^{70}$ Establishing reasonable suspicion, therefore, to support a carefully limited investigatory response to an anonymous car bomb tip, would seem to provide the necessary ingredient to render the response reasonable.

\section{Anonymous Tips, Existing Facts, and Reasonable Suspicion}

The exceptions above leave a gap between the probable cause-and accompanying exceptions-needed for a full evidentiary search and the lack of individualized suspicion that justifies the special needs exception. The investigatory and protective needs of the anonymous tip highlighted

68. Edmond, 531 U.S. at 37.

69. See id; see also Ashcroft v. al-Kidd, 131 S. Ct. 2074, 2081-82 (2011). In Ashcroft, Justice Scalia suggested that the absence of individualized suspicion is an aspect of a valid special needs program:

Apart from those cases, we have almost uniformly rejected invitations to probe subjective intent. There is one category of exception, upon which the Court of Appeals principally relied. In Edmond, we held that the Fourth Amendment could not condone suspicionless vehicle checkpoints set up for the purpose of detecting illegal narcotics. Although we had previously approved vehicle checkpoints set up for the purpose of keeping off the road unlicensed drivers, or alcohol-impaired drivers; and for the purpose of interdicting those who illegally cross the border; we found the drug-detection purpose in Edmond invalidating because it was ultimately indistinguishable from the general interest in crime control. In the Court of Appeals' view, Edmond established that programmatic purpose is relevant to Fourth Amendment analysis of programs of seizures without probable cause.

That was mistaken. It was not the absence of probable cause that triggered the invalidating-purpose inquiry in Edmond. To the contrary, Edmond explicitly said that it would approve checkpoint stops for general crime control purposes that were based upon merely some quantum of individualized suspicion. Purpose was relevant in Edmond because programmatic purposes may be relevant to the validity of Fourth Amendment intrusions undertaken pursuant to a general scheme without individualized suspicion.

Ashcroft, $131 \mathrm{~S}$. Ct. at 2081 (citations omitted) (internal quotation marks omitted).

70. See Gould \& Stern, supra note 53, at 818-23. 
by the opening hypothetical fall into this gap. However, because of the unquestioned protective purpose of any investigatory response to such a tip, the situation seems to also implicate the Terry doctrine, which could provide a justification for a carefully limited search to "confirm or deny" the imminent threat of violent harm to police and others. In Terry $v$. Ohio, ${ }^{71}$ the Supreme Court held that a cursory inspection for the purposes of protecting police or others around them from a threat of violent crime is justified on the lower threshold characterized by the Court as reasonable suspicion. ${ }^{72}$ Unlike probable cause, reasonable suspicion relies heavily on police instincts and intuition, requiring only that those instincts and intuition be based on some objective articulable fact. ${ }^{73}$ If the car that police suspect contains a bomb is treated as the analogue to the suspect's outer clothing in Terry, then a search sufficient in scope to confirm or deny the risk that the car is "armed and dangerous" would appear to be a legitimate extension of the doctrine. In the alternative, reasonable suspicion would seem to satisfy the causal requirement for invoking the special needs doctrine after establishing individualized suspicion. There are, however, two obstacles to relying on the Terry doctrine to justify a seizure or search in response to a car bomb tip. First, based on existing jurisprudence, corroborating openly available existing information (as opposed to a prediction of future conduct) provided by the tip is insufficient to establish reasonable suspicion. Second, if a search of the automobile's concealed interior is necessary to confirm or deny the car bomb risk, the scope of the intrusion becomes indistinguishable from a full-blown evidentiary search.

Two Supreme Court decisions analyzing whether an anonymous tip established reasonable suspicion indicate the insufficiency of the type of tip hypothesized in this Article: Alabama v. White ${ }^{74}$ and Florida v. J.L. ${ }^{75}$ In White, the Court held that corroboration of a tip's predictive but openly available information did not establish probable cause. ${ }^{76}$ Unlike Gates, the openly available information precluded the conclusion that the

71. Terry v. Ohio, 392 U.S. 1 (1968).

72. See id. at 27. The Court stated:

[T] here must be a narrowly drawn authority to permit a reasonable search for weapons for the protection of the police officer, where he has reason to believe that he is dealing with an armed and dangerous individual, regardless of whether he has probable cause to arrest the individual for a crime. The officer need not be absolutely certain that the individual is armed; the issue is whether a reasonably prudent man in the circumstances would be warranted in the belief Id. that his safety or that of others was in danger.

73. See, e.g., Illinois v. Gates, 462 U.S. 213, 244 (1983); Terry, 392 U.S. at 29-30.

74. Alabama v. White, 496 U.S. 325 (1990).

75. Florida v. J.L., 529 U.S. 266 (2000).

76. See White, 496 U.S. at 332. 
informant obtained the information as the result of "insider access" to the alleged criminal activity. ${ }^{77}$ The Court did, however, hold that corroboration of even openly available predictive information provided sufficient indicia of reliability to establish the lower standard of reasonable suspicion. ${ }^{78}$ As a result, while the police were justified in conducting a brief investigatory seizure of the defendant to confirm or deny this suspicion, there was insufficient cause to justify a full search of the defendant's automobile based solely on the tip. ${ }^{79}$

In J.L., the Court addressed the effect of a tip that did not even provide the type of open source predictions of future activities involved in White. ${ }^{80}$ In that case, police responded to an anonymous tip that an individual was currently located at a specifically identified bus stop wearing a particular article of clothing, and that this individual was carrying a concealed weapon. ${ }^{81}$ When police arrived at the location provided by the tip, they observed a suspect matching the description provided by the informant. ${ }^{82}$ Police then seized the suspect and frisked him for weapons, resulting in discovery of the concealed weapon and arrest of the suspect. ${ }^{83}$ The Supreme Court held that both the seizure and search were unreasonable, concluding that the tip was insufficient to even establish reasonable suspicion pursuant to the White standard. ${ }^{84}$ In reaching this conclusion, the Court emphasized that nothing about the tip was even predictive. ${ }^{85}$ Instead, all the police had corroborated were facts that anyone could see and report: that someone was standing at a bus stop wearing a certain article of clothing. ${ }^{86}$ As a result, the tip provided no objective basis for a reviewing court to validate the reasonableness of the police suspicion it generated.

Applying these precedents to the hypothetical addressed in this Article that corroboration of an anonymous tip that a car containing a

77. Id. (noting that anyone can report apparent and readily available facts that preexist at the time of a tip).

78. See id. ("What was important was the caller's ability to predict respondent's future behavior, because it demonstrated inside information-a special familiarity with respondent's affairs.").

79. See id. ("Although it is a close case, we conclude that under the totality of the circumstances the anonymous tip, as corroborated, exhibited sufficient indicia of reliability to justify the investigatory stop of respondent's car.").

80. J.L., 529 U.S. at 268.

81. See id.

82. See id.

83. See id.

84. See id. at 271 ("The tip in the instant case lacked the moderate indicia of reliability present in White and essential to the Court's decision in that case.").

85. See J.L., 529 U.S. at 271 ("The anonymous call concerning J.L. provided no predictive information and therefore left the police without means to test the informant's knowledge or credibility.").

86. See id. 
bomb is parked at a certain location fails to establish not only probable cause, but also reasonable suspicion. As a result, even a vehicle analogue of a Terry seizure and/or Terry search-as opposed to a fullblown evidentiary search justified by probable cause-would not be reasonable. Nor is this conclusion altered by application of either the automobile exception or the exigent circumstances exception, both of which rely fundamentally on the existence of probable cause.

If police receive a generalized tip of an imminent car bomb attack, random checkpoint searches would almost certainly be considered a reasonable response. If however, the tip provides specific focus for the police that a particular vehicle at a particular location contained a car bomb, a focus verified by corroborating investigation, the individualized suspicion would foreclose use of the special needs exception. And, based on the existing standards established by Alabama $v$. White and Florida v. J.L., confirming that the vehicle identified by the informant is in fact at the alleged location will not be sufficient to establish reasonable suspicion. Nonetheless, doing nothing in response to such a tip seems itself unreasonable. Accordingly, some compromise is necessary-a compromise that aligns the need to respond effectively to such threats with the test for reasonableness.

\section{NEED AND RESPONSE: SHOULD REASONABLENESS TURN ON EMERGING THREATS?}

At first blush, a proposal adjusting the test for assessing Fourth Amendment reasonableness in order to satisfy the investigatory needs of law enforcement may seem radical. However, existing Fourth Amendment jurisprudence indicates that the meaning of reasonableness must be responsive to the pragmatic realities of law enforcement investigations. ${ }^{87}$ Both Gates and Terry were built on just such a pragmatic foundation. ${ }^{88}$ Indeed, in setting the conditions for adopting a more flexible continuum of cause to justify a cursory search, the Terry Court emphasized the importance of adopting a more workable standard to meet the realistic needs of law enforcement. ${ }^{89}$ The Court noted that requiring a unitary probable cause standard for any search-and excluding evidence obtained without satisfying that standard-would be an ineffective deterrent to such searches when the police perceived the

87. See Anthony C. Coveney, When the Immovable Object Meets the Unstoppable Force: Search and Seizure in the Age of Terrorism, 31 AM. J. TRIAL ADVOC. 329, 373-81 (2007).

88. See Illinois v. Gates, 462 U.S. 213, 243-44 (1983); Terry v. Ohio, 392 U.S. 1, 30-31 (1968).

89. See Terry, 392 U.S. at 30-31. 
need to conduct the search as more compelling than the need to preserve evidence for admission at trial:

The exclusionary rule has its limitations, however, as a tool of judicial control. ... [I]n some contexts, the rule is ineffective as a deterrent. Street encounters between citizens and police officers are incredibly rich in diversity.... [A] stern refusal by this Court to condone such activity does not necessarily render it responsive to the exclusionary rule. Regardless of how effective the rule may be where obtaining convictions is an important objective of the police, it is powerless to deter invasions of constitutionally guaranteed rights where the police either have no interest in prosecuting or are willing to forgo successful prosecution in the interest of serving some other goal.

Proper adjudication of cases in which the exclusionary rule is invoked demands a constant awareness of these limitations. ... [A] rigid and unthinking application of the exclusionary rule, in futile protest against practices which it can never be used effectively to control, may exact a high toll in human injury and frustration of efforts to prevent crime. No judicial opinion can comprehend the protean variety of the street encounter, and we can only judge the facts of the case before us. ${ }^{90}$

Terry therefore supports the conclusion that a modified test for determining when an informant's tip is sufficient to trigger an investigation of an impending terrorist car bomb attack is consistent with the reasonableness touchstone of the Fourth Amendment. ${ }^{91}$ This modification would permit suspicion to be considered reasonable based on independent verification of the car bomb location, without requiring validation of predictions beyond the location and description of the vehicle provided by the tip. ${ }^{92}$ When coupled with the scope inherent in the protective purpose of a search conducted pursuant to Terry, ${ }^{93}$ a

90. Id. at 13-15 (emphasis added) (footnotes omitted).

91. See id. at 30-31. It is undisputed that Terry did not lower the threshold of cause that renders a full evidentiary search reasonable. Nor will this Article argue for such an outcome. Instead, it proposes offsetting the expanded search authority of an adjusted standard of reasonable suspicion and an accordant scope expansion with a limited-use doctrine for evidence seized during a search based on this reduced quantum of proof. Accordingly, the proposal will mitigate the resulting increased risk to privacy. In so doing, it strikes a reasonable balance between the authority to conduct what may in effect be indistinguishable from a full evidentiary search in reliance on such tips and the liberty interests of the public.

92. But see Alabama v. White, 496 U.S. 325, 332 (1990).

93. Terry, 392 U.S. at 29. 
prompt and decisive law enforcement reaction to such a tip not only would be logical, but also legally reasonable. ${ }^{94}$

Accordingly, aligning the definition of Fourth Amendment reasonableness with the legitimate needs of law enforcement and society is anything but radical, but rather is consistent with the core rationale of the Terry doctrine. In Terry, the Court held that the quantum of cause for reasonable suspicion rendered reasonable a brief investigatory seizure and cursory protective pat down-what the Court indicated was euphemistically known as a stop and frisk. ${ }^{95}$ Subsequent decisions by the Court extended the Terry protective search rationale to other contexts. For example, police are permitted to conduct not only a cursory pat down of the clothing of an individual they suspect is armed and dangerous, but also a "protective" sweep of the interior of a home following arrest of an occupant based on reasonable suspicion there are confederates in the home who could endanger the officers. ${ }^{96}$ Similarly, police are permitted to perform a cursory inspection of the interior compartment of an automobile following a traffic stop, prior to allowing the driver back into the car, based on reasonable suspicion that a weapon may be in a readily accessible location. ${ }^{97}$

All of these extensions of Terry search authority still require, however, reasonable suspicion that the officers or others face a genuine risk. If, as noted above, corroboration of existing facts provided by an anonymous tip is insufficient to establish reasonable suspicion, the essential predicate for considering extending Terry authority to a responsive search or seizure of a suspected car bomb would be lacking. It is for this reason that in this unique context, such corroboration should be sufficient to establish the requisite reasonable suspicion.

\section{A. A Terrorism-Specific Test for Reasonable Suspicion?}

What transforms mere suspicion to reasonable suspicion? This inquiry was a key aspect of the Terry decision, and while the exact meaning of reasonable suspicion remains somewhat cryptic, two requirements seem clear. First, the suspicion must be based on some

94. See also MiL. R. Evid. 313(b).

95. Terry, 392 U.S. at 29.

96. Maryland v. Buie, 494 U.S. 325, 334 (1990) ("[A]s an incident to [an] arrest the officers could, as a precautionary matter and without probable cause or reasonable suspicion, look in closets and other spaces immediately adjoining the place of arrest from which an attack could be immediately launched.").

97. See Michigan v. Long, 463 U.S. 1032, 1051 (1983) ("[T]he balancing required by Terry clearly weighs in favor of allowing the police to conduct an area search of the passenger compartment to uncover weapons, as long as they possess an articulable and objectively reasonable belief that the suspect is potentially dangerous."). 
objectively verifiable fact in order to facilitate subsequent judicial validation. ${ }^{98}$ Second, as a result, pure subjective police instinct could never be sufficient. As the Court noted:

And in justifying the particular intrusion the police officer must be able to point to specific and articulable facts which, taken together with rational inferences from those facts, reasonably warrant that intrusion. The scheme of the Fourth Amendment becomes meaningful only when it is assured that at some point the conduct of those charged with enforcing the laws can be subjected to the more detached, neutral scrutiny of a judge who must evaluate the reasonableness of a particular search or seizure in light of the particular circumstances. And in making that assessment it is imperative that the facts be judged against an objective standard: would the facts available to the officer at the moment of the seizure or the search "warrant a man of reasonable caution in the belief" that the action taken was appropriate? Anything less would invite intrusions upon constitutionally guaranteed rights based on nothing more substantial than inarticulate hunches, a result this Court has consistently refused to sanction. ${ }^{99}$

Thus, according to Terry, an officer's subjective suspicion becomes constitutionally reasonable when it is derived from objective facts that reasonably validate the suspicion-facts that are subsequently verifiable by a reviewing court assessing the reasonableness of the suspicion. ${ }^{100}$

Normally, police observations of activity that seems suspicious produce the constitutionally required objective fact that renders the suspicion reasonable and justifies a brief investigatory seizure-or, in more limited circumstances, a protective cursory search for weapons or other sources of imminent danger. However, just as police must often rely on informants to establish probable cause, reasonable suspicion may sometimes result from an informant's tip. Because, however, the standard of reasonable suspicion is lower than that of probable cause, in Alabama v. White the Court endorsed an analogous reduction in the detail and quality of the tip when police rely on it to establish reasonable suspicion. ${ }^{101}$

To establish reasonable suspicion, however, corroboration of the tip's predictions - even if the nature of the predictions did not indicate insider access to the suspect's criminal activity — seemed to be essential.

98. See Terry, 392 U.S. at 21 ("[I]n justifying the particular intrusion the police officer must be able to point to specific and articulable facts which, taken together with rational inferences from those facts, reasonably warrant that intrusion.").

99. Id. at 21-22 (emphasis added) (footnotes omitted) (citations omitted).

100. See id.

101. See Alabama v. White, 496 U.S. 325, 328-29 (1990). 
The Court subsequently confirmed this in Florida v. J.L. in a unanimous opinion, ruling that a stop and frisk resulting from a non-predictive tip violated the Fourth Amendment. ${ }^{102}$ The Court distinguished the case from White precisely because the information provided was both publicly available and non-predictive. ${ }^{103}$ As a result, it provided no objective basis for police to conclude that the assertion of concealed criminal activity was reliable. Furthermore, the fact that the police validated the reliability of the tip after the frisk was irrelevant, because this in no way related to the reliability of the tip at the time the police commenced the intrusion. According to the Court:

The tip in the instant case lacked the moderate indicia of reliability present in White and essential to the Court's decision in that case. The anonymous call concerning J.L. provided no predictive information and therefore left the police without means to test the informant's knowledge or credibility. That the allegation about the gun turned out to be correct does not suggest that the officers, prior to the frisks, had a reasonable basis for suspecting J.L. of engaging in unlawful conduct: The reasonableness of official suspicion must be measured by what the officers knew before they conducted their search. All the police had to go on in this case was the bare report of an unknown, unaccountable informant who neither explained how he knew about the gun nor supplied any basis for believing he had inside information about J.L. If White was a close case on the reliability of anonymous tips, this one surely falls on the other side of the line. ${ }^{104}$

Thus, the combination of anonymity of the source and the non-predictive nature of the information corroborated by independent police investigation provided nothing objective to transform subjective suspicion into reasonable suspicion. ${ }^{105}$ In this regard, the Court emphasized that a tip cannot provide reasonable suspicion merely because police verify it is accurate in identifying an individual; what is required is police validation that the assertion of concealed criminality is reliable, which requires more from the tip than merely providing open non-predictive information:

102. Florida v. J.L, 529 U.S. 266,274 (2000) ("[W]e hold that an anonymous tip lacking indicia of reliability ... does not justify a stop and frisk whenever and however it alleges the illegal possession of a firearm.").

103. See id. at 269-72.

104. Id. at 271.

105. See Kit Kinports, Veteran Police Officers and Three-Dollar Steaks: The Subjective/Objective Dimensions of Probable Cause and Reasonable Suspicion, 12 U. PA. J. Const. L. 751, 774 (2010) ("[A] police officer's subjective good faith is insufficient to validate law enforcement techniques that do not satisfy objective standards of conduct."). 
An accurate description of a subject's readily observable location and appearance is of course reliable in this limited sense: It will help the police correctly identify the person whom the tipster means to accuse. Such a tip, however, does not show that the tipster has knowledge of concealed criminal activity. The reasonable suspicion here at issue requires that a tip be reliable in its assertion of illegality, not just in its tendency to identify a determinate person. ${ }^{106}$

Applying this same reasoning to the hypothetical anonymous tip that a car bomb is located at a certain location, even if the tip describes the location and the vehicle with precise detail, J.L. suggests that police corroboration of these facts would fail to establish not only probable cause, but even reasonable suspicion.

In J.L, the state, however, offered an alternate rationale for the search based on the fact that, unlike in White, police were not suspicious of drug possession, but of weapon possession. According to the state, the nature of the danger associated with weapon possession justified a reduced standard to establish reasonable suspicion-a theory directly on point, if not more compelling, with the car bomb hypothetical. ${ }^{107}$ The Court rejected this proposed "firearm exception," suggesting that the nature of the threat cannot alter the assessment of what amounts to reasonable suspicion:

A second major argument advanced by Florida and the United States as amicus is, in essence, that the standard Terry analysis should be modified to license a "firearm exception." Under such an exception, a tip alleging an illegal gun would justify a stop and frisk even if the accusation would fail standard pre-search reliability testing. We decline to adopt this position. ${ }^{108}$

This aspect of the decision was not, however, broad enough to categorically foreclose the possibility of the modification the state proposed. While the Court rejected the proposed adjustment to reasonable suspicion in the case of a tip of an armed suspect, it offered an important qualifier, one directly on point with the proposal of this article:

The facts of this case do not require us to speculate about the circumstances under which the danger alleged in an anonymous tip might be so great as to justify a search even without a showing of reliability. We do not say, for example, that a report of a person carrying a bomb need bear the indicia of reliability we demand for a

106. J.L., 529 U.S. at 272.

107. See id.

108. Id. 
report of a person carrying a firearm before the police can constitutionally conduct a frisk. ${ }^{109}$

This qualifier opens a window that logically extends to the threat of serious terrorist attacks. The Court suggested that the level of reliability required to establish reasonable suspicion to justify a cursory search of a person suspected of carrying a bomb may be lowered from that normally required to search even a person suspected of being armed. Why would this be reasonable? The answer seems clear: the nature of the threat alters the assessment of what qualifies as a reasonable police response. If the threat is one armed individual, that will produce suspicion of some risk to police and possibly bystanders, but not enough suspicion to justify a Fourth Amendment intrusion based on the tip alone. However, if the same type of tip produces suspicion of a threat on a much higher order of magnitude - the type of threat resulting from a suicide bomber-then the reduced indicia of reliability would not be the exclusive focus of the reasonableness assessment. Instead, the threat itself, and perhaps more importantly what a reasonable officer would be expected by society to do in response to such a threat, would be an additional element in the analysis.

If such a non-predictive tip from a source of unknown veracity/credibility may be sufficient to justify a cursory search of an individual for the exclusive protective purpose, it would seem even more reasonable to justify a protective cursory search of an automobile. Not only are automobiles traditionally considered to carry a reduced expectation of privacy, ${ }^{110}$ but it also seems axiomatic that the gravity of a bomb risk would be substantially greater for a car bomb than for an individual suicide bomber. ${ }^{111}$ Thus, the qualifier offered by the Court in $J . L$. seems to be the ideal foundation for resolving the dilemma of police response to the anonymous tip of a car bomb.

Unless such a threat-based test for reasonable suspicion is adopted, the inherent incongruity between what police will consider a reasonable response to a car bomb tip and what is lawfully permitted will persist.

109. Id. at 273-74.

110. See California v. Carney, 471 U.S. 386, 392-93 (1985) (noting that a vehicle's (1) ready mobility and (2) "use as a licensed motor vehicle subject to a range of police regulation inapplicable to a fixed dwelling" are the two traditional justifications for the automobile exception); see also South Dakota v. Opperman, 428 U.S. 364, 367 (1976) ("Besides the element of mobility, less rigorous warrant requirements govern because the expectation of privacy with respect to one's automobile is significantly less than that relating to one's home or office.").

111. Compare VBIEDs, supra note 5, with Suicide Bombs, GlobalSECURITY.ORG, http://bit.ly/lapfuWj (last visited Aug. 26, 2013). 
Eliminating such an incongruity is consistent with the rationale that led the Court to endorse the Terry doctrine. ${ }^{112}$

However, allowing a search-even if cursory and limited in scope to protecting the police and public- on what in any other context would not even amount to reasonable suspicion also implicates another concern addressed in Terry: the risk of police abuse. In Terry, the Court compensated for this risk by establishing the reasonable suspicion requirement, which as the Court noted would preserve the role of the judiciary in checking police abuse by requiring the police to establish some objective basis for the suspicion that led to the minimal intrusion. According to the Court:

Under our decision, courts still retain their traditional responsibility to guard against police conduct which is over-bearing or harassing, or which trenches upon personal security without the objective evidentiary justification which the Constitution requires. When such conduct is identified, it must be condemned by the judiciary and its fruits must be excluded from evidence in criminal trials. ${ }^{113}$

Adopting a test for reasonable suspicion that does not even satisfy the minimal requirements of Alabama $v$. White-a test that would validate the type of anonymous non-predictive tip ruled insufficient in Florida $v$. J.L.- would effectively nullify this limited judicial oversight function. J.L.-type tips provide virtually no indicia of reliability derived from the informant's track record of accuracy or the informant's basis of knowledge of the suspect's activities (by verifying predictions made by the informant). As a result, there is no objective indicator of reliability for a court to assess in a subsequent suppression hearing, thus eviscerating the inherent limit on the risk of police misconduct built into the Terry doctrine. All a court could consider in such a case is the reliability of identifying a determinate person or thing, which, as the Court noted in J.L., in no way provides an objective indicator of the reliability of the informant's assertion of concealed criminal activity. Nonetheless, because delaying a response to even this limited indication of an impending mass casualty car bomb attack is itself inherently unreasonable, extending the threat-based adjustment to a Fourth Amendment principle as suggested in J.L. seems essential. Even assuming, however, that corroborating the existing facts provided by an anonymous car bomb tip will establish reasonable suspicion, the

112. See David A. Harris, Particularized Suspicion, Categorical Judgments: Supreme Court Rhetoric Versus Lower Court Reality Under Terry v. Ohio, 72 ST. JOHN's L. Rev. 975, 981-87 (1998) (noting that Terry was a "grand compromise" to address this dilemma).

113. Terry v. Ohio, 392 U.S. 1, 15 (1968) (emphasis added). 
reasonable scope of the permissible response will also present a Fourth Amendment challenge.

\section{B. Scope: A Logical Expansion}

Objectively reasonable suspicion that the officer, or those around the officer, faces danger of immediate violent harm is the substantive justification for all Terry-based searches. But scope is also a critical element related to the reasonableness of these searches. In each context, the Court has endorsed a search that will often result in discovery of contraband or other evidence precisely because the primary purpose of the search is not to discover evidence in order to build a case-a true evidentiary search-but instead to protect life. ${ }^{114}$ The scope of such searches, therefore, may not extend beyond what is necessary to confirm or deny the suspicion of this imminent danger. How then, can this twopronged justification for the Terry search apply to the car bomb anonymous tip dilemma? The answer must involve more than merely adjustment to the substantive requirements for establishing reasonable suspicion; it also requires rethinking the scope of a permissible Terry search of an automobile in response to the car bomb threat. Only in so doing is it possible to achieve the underlying rationale of Terry in the terrorism tip context.

The reasonableness of any Terry-based search or seizure has always been contingent on the narrowly tailored scope of the intrusion. Terry stops, defined as brief investigatory seizures, are limited in duration to the amount of time reasonably necessary to confirm or deny the suspicion. ${ }^{115}$ Terry searches were originally limited to a cursory patdown of the suspect's outer clothing to confirm or deny the suspicion that the suspect is armed and dangerous ${ }^{116}$ and subsequently extended to other contexts. ${ }^{17}$ In all of these situations, the scope of the Terry search authorization is carefully limited to only those places police must reasonably search to exclude the risk of imminent potential harm. The Supreme Court's consistent emphasis of this limited scope has always been motivated by the need to prevent the Terry search from becoming a

114. See Thomas K. Clancy, The Role of Individualized Suspicion in Assessing the Reasonableness of Searches and Seizures, 25 U. MEM. L. REV. 483, 552-53 (1995) (noting that, as the doctrine developed, the Court became more interested in officer safety than the invasion of privacy).

115. See Terry, 392 U.S. at 26.

116. See id. at 30.

117. See Daniel C. Isaacs, Miranda 's Application to the Expanding Terry Stop, 18 J.L. \& POL'Y 383, 387-93 (2009) (noting that the propensity of lower courts to defer to officer safety on a case-by-case basis led to the progressive expansion of Terry after the initial decision in 1968). 
substitute for a full evidentiary search. When, however, a genuine protective purpose exists, the Court has been favorably inclined to extend the scope of a Terry-based search to situations beyond just a cursory pat down of an individual suspected of being armed and dangerous. Indeed, Justice Harlan's concurrence in Terry emphasized that when a Terry seizure is predicated upon reasonable suspicion that the suspect is armed and dangerous, the protective search should be automatic:

Where such a stop is reasonable, however, the right to frisk must be
immediate and automatic if the reason for the stop is, as here, an
articulable suspicion of a crime of violence. Just as a full search
incident to a lawful arrest requires no additional justification, a
limited frisk incident to a lawful stop must often be rapid and routine.
There is no reason why an officer, rightfully but forcibly confronting
a person suspected of a serious crime, should have to ask one
question and take the risk that the answer might be a bullet. ${ }^{118}$

Justice Harlan's automatic search approach may be the pragmatic reality of Terry in practice, but the Court has never adopted this justification for a Terry search. Instead, reasonable suspicion must be established to justify the search. Nonetheless, Justice Harlan's recognition that, once a suspect is detained based on reasonable suspicion that violent crime is afoot, the police must be granted almost absolute discretion to engage in a Terry-based search to protect police and others from imminent harma protective search-is logical. Any other approach would inject a dangerous level of hesitation into the decision-making processhesitation that Justice Harlan (and the Terry majority) recognized might prove deadly.

Extending this reasoning to the car bomb context would first require an assertion of control over the vehicle. Police could cordon the area and prevent access to the vehicle, which would qualify as a seizure. ${ }^{119}$ The reasonable suspicion justifying the seizure would, as in Terry, almost always then automatically justify a protective search. How then should the reasonable scope of that search be defined?

In Michigan v. Long, ${ }^{120}$ the Supreme Court addressed the scope of a Terry-based protective search of an automobile, and endorsed a cursory inspection of a limited area of the automobile interior. ${ }^{121}$ However, it is critical to note that the justification for that search was unrelated to the

118. Terry, 392 U.S. at 33 (Harlan, J., concurring).

119. See United States v. Jacobsen, 466 U.S. 109, 113 (1984) ("A seizure of property occurs when there is some meaningful interference with an individual's possessory interests in that property.") (internal quotation marks omitted).

120. Michigan v. Long, 463 U.S. 1032 (1983).

121. See id. at 1049. 
justification for the initial stop-the stop was independently justified based on a traffic violation. Thus, Long offers two important guideposts for resolving this scope question. First, a car, like an individual, may be the subject of a Terry protective search. Second, as in Terry itself, the scope of that search must be assessed based on the threat associated with the car. In Long, the threat was ready access to a weapon when the driver re-entered the car. ${ }^{122}$ Accordingly, the scope of the search was limited to those areas not observable from the exterior of the car where a driver might gain immediate access to a weapon. ${ }^{123}$ It would be erroneous, however, to read Long as foreclosing a search of other concealed areas of the car in all situations. Instead, the reasonableness of such an expanded scope must be contingent on the threat triggering the reasonable suspicion.

In the case of an automobile seized on suspicion of being a car bomb, the type of limited search conducted in Long will be insufficient to respond to the threat. Ideally, evidence of the bomb will be observable from the exterior of the automobile (as occurred in the Times Square case), ${ }^{124}$ either by the naked eye or with the aid of some sensory enhancement, such as a dog trained to detect explosives. In this situation, even if the police must seize the automobile while conducting the observation (which will only be the case if they meaningfully interfere with a possessory interest), the external observation will produce probable cause, and the subsequent search of the automobile will be reasonable absent a warrant based on either the exigent circumstances or the automobile exceptions to the warrant requirement. Any contraband observed during that probable cause search will then be subject to plain view seizure pursuant to existing Fourth Amendment principles. ${ }^{125}$

If, however, police respond to a car bomb tip and cannot confirm or deny the presence of a bomb in the automobile with external observation, the automobile becomes the physical analogue of the hypothetical suicide bomber in Florida v. J.L. ${ }^{126}$ In this situation, simply seizing the automobile might be insufficient to achieve the legitimate protective purpose triggered by the tip. Instead, police must be authorized to conduct a search into concealed areas of the automobile where a bomb may be located. This would permit, for example, police to use some

122. See id., 463 U.S. at 1048 ("[W]e . . expressly recognize[] that suspects may injure police officers and others by virtue of their access to weapons, even though they may not themselves be armed.").

123. See id.

124. See Baker \& Rashbaum, supra note 3.

125. See supra note 38.

126. See supra notes $109-12$ and accompanying text. 
intrusive capability to penetrate the trunk or the concealed portions of the passenger compartment to search for evidence of a bomb. If identified, further action would be justified based on a probable cause-based plain view seizure of the contraband or the vehicle itself. If, as Florida v. J.L. suggests, the search of an individual suspected of carrying a bomb would be reasonable based on a non-predictive anonymous tip, ${ }^{127}$ then it seems only logical that an analogous search of an automobile would also be reasonable based on the same information. While the scope of the search would certainly be more expansive than that endorsed in Michigan $v$. Long, reasonableness would turn on the relationship of the scope to the threat-a consistent thread that runs through all Terry protective search jurisprudence. ${ }^{128}$

These adjustments-to both the substantive requirement for establishing reasonable suspicion and the scope of the permissible response triggered by reasonable suspicion of a car bomb attack-will also significantly expand the authority of police to search automobiles on the bare minimum of objectively verifiable suspicion. As a result, these adjustments will in large measure nullify existing limitations on the opportunity to, and consequence of, invocation of the Terry doctrine, potentially allowing for the introduction of incriminating evidence wholly unrelated to the alleged terrorist suspicion. In response, I propose that some alternate method of checking abuse of this search justification is required. Because permitting the police to base that judgment on such minimal objective indicia of an anonymous tip's reliability will disable meaningful judicial critique of police judgment, the alternate method should take the form of a limitation on the use of evidence derived from the protective search.

When coupled with a limitation on admissibility of evidence found in plain view but unrelated to the threat that triggered the proposed protective search, this expansion of Terry search authority strikes a reasonable balance between protecting the public and protecting the individual from subterfuge or the lying informant. The law will authorize what is, by any measure, a reasonable response to a tip of an impending terrorist attack in an era where the threat of the lone wolf selfradicalized terrorist poses an increasingly serious risk. But the law will also impose a rational limitation to prevent this search based on minimal objectively verifiable suspicion to be used as a ploy to target individuals and avoid the otherwise more demanding requirements of the Fourth Amendment.

127. See Florida v. J.L., 529 U.S. 266, 273-74 (2000).

128. See supra notes $109-12$ and accompanying text. 


\section{PRotections Against OVER-Breadth: Limiting THE USE OF EVIDENCE SEIZEd DURING A PROTECTIVE VeHICLE SEARCH}

Extending the protective Terry search into concealed areas of an automobile in such situations would certainly enhance police efforts to neutralize the threat of terrorist car bombs or other weapons capable of inflicting mass casualties. However, this expansion will also permit the police to conduct what will in practice be indistinguishable from a full evidentiary search of the vehicle on a quantum of proof that has never been considered sufficient to justify such an intrusion. ${ }^{129}$ Terrorism is therefore not the exclusive risk implicated by empowering police to engage in timely and effective response to these type of anonymous tips; permitting search or seizure based on information that lacks even minimal objective indicia of reliability creates its own risk to liberty and the privacy protected by the Fourth Amendment. This risk is inherent in potential overreaction to the threat of terrorism, ${ }^{130}$ police abuse of this expanded response authority, or even information provided to police to falsely implicate the target of the tip. It is therefore essential to recognize the risk. ${ }^{131}$ Thus, any proposed expansion of government authority to conduct searches or seizures responsive to the unique threats of terrorism, and especially the car bomb, should be tailored not only to facilitate the legitimate police needs, but also to protect the citizenry from abuse of their constitutional rights via police overreach. ${ }^{132}$

Two possible limitations on the use of evidence seized using this "terrorism tip" Terry expansion could be adopted to offset this risk. The first would require exclusion of any evidence seized pursuant to such a search unless the evidence is relevant to proving a terrorism-related allegation. Placing police on notice that any evidence of crime unrelated to their asserted protective search justification will be subject to exclusion will deter police from invoking this exception absent a genuine concern of imminent terrorist attack, thereby reducing the risk that police will use this exception as a subterfuge to avoid normal evidentiary search requirements. A second alternative would be a more tailored limited-use rule, triggered when the asserted protective search fails to uncover any

129. See Jeremy J. Calsyn et al., Investigation and Police Practices: Warrantless Searches and Seizures, 86 GEO. L.J. 1214, 1259-63 (1998).

130. See generally Erwin Chemerinsky, Losing Liberties: Applying a Foreign Intelligence Model to Domestic Law Enforcement, 51 UCLA L. REv. 1619 (2004) (arguing that the threat of domestic terrorism has resulted in the government adopting investigatory methods heretofore limited to government counter-terrorism operations conducted outside the United States).

131. See generally Vernon Elledge, Searches and Seizures-Evidence Illegally Obtained Inadmissible in Criminal Trial, 5 TEX. L. REV. 424 (1927).

132. See generally Akhil Reed Amar, Fourth Amendment First Principles, 107 HARV. L. REV. 757 (1994). 
evidence related to the alleged terrorist threat, but does result in the seizure of unrelated contraband. In such cases, admissibility of this unrelated contraband evidence against a defendant will require the prosecution to establish by clear and convincing evidence that the protective search was in fact legitimate and not a pretense to avoid the normal reasonableness requirements of the Fourth Amendment. ${ }^{133}$ The first of these limitations would certainly penalize the police for invoking alleged car bomb reasonable suspicion as a subterfuge to pursue a hunch or to otherwise harass an individual. However, it is also a draconian limitation, depriving the government of the opportunity to utilize highly probative evidence against a defendant simply because the police suspicion proved to be erroneous, with no proof of police bad faith. Such an extreme limitation would certainly run counter to the ongoing Supreme Court trend to relax the impact of the exclusionary rule. ${ }^{134}$ In contrast, the alternative limitation-triggering a presumption of inadmissibility whenever a suspect establishes that she was the target of police suspicion unrelated to a bomb threat-is less extreme, but also less protective. Once this pre-existing suspicion is established, evidence seized during the asserted protective search will be admissible only if the government establishes by clear and convincing evidence the search was unrelated to the pre-existing suspicion. ${ }^{135}$

\section{A. Evidence Exclusion: The Ultimate Subterfuge Deterrent}

Of these two options for protecting against police abuse, the absolute exclusionary rule would provide the strongest deterrent against

133. Cf. United States v. Rodriguez-Morales, 929 F.2d 780, 787 (1st Cir. 1991) ("As long as ... [seizure] pursuant to the community caretaking function is not a mere subterfuge for investigation, the coexistence of investigatory and caretaking motives will not invalidate the seizure.").

134. See Albert W. Alschuler, The Exclusionary Rule and Causation: Hudson v. Michigan and Its Ancestors, 93 IowA L. REV. 1741, 1768 (2008) (going so far as to question whether the Supreme Court-or some legislative body-may "scrap" the exclusionary rule in its entirety).

135. As noted above, this presumptive inadmissibility approach is based on Military Rule of Evidence 313, which establishes a limitation on the use of evidence at courtmartial seized during the course of a military inspection. Because command inspections are an important and routine aspect of military life, the use of inspections to bypass the normal probable cause requirement for conducting an evidentiary search creates a genuine risk of command abuse of service members' rights, the same type of risk inherent in a threat-based reasonable suspicion standard. A military inspection is authorized for the primary purpose of ensuring the health, welfare, and fitness for duty of the military unit, not for the discovery of evidence of criminal activity. In this regard, the inspection is the military analogue to the special needs doctrine. Accordingly, when evidence of criminal activity is discovered during an inspection, that evidence is normally admissible at trial by court-martial precisely because its discovery was not the primary purpose of the intrusion. See MIL. R. EvID. 313. 
police subterfuge. This rule would be based on the premise that discovery of the contraband that generated the protective search-a bomb or bomb-making materials-would be required as a post-hoc validation of the tip's reliability (the outcome proposed by Florida in Florida v. J.L. but rejected by the Court). ${ }^{136}$ That discovery would validate the police reliance on the tip and render the search reasonable by excluding the inference that either the tipster "set up" a fellow citizen, or that the police fabricated the tip in order to conduct a subterfuge evidentiary search. Discovery of contraband unrelated to the suspected threat would, in the alternative, establish that the tip was at best unreliable, and at worst fabricated as a subterfuge to seize evidence otherwise beyond the lawful reach of a genuine protective search.

This type of expansive exclusionary rule is, of course, unique in the context of Fourth Amendment jurisprudence and also inconsistent with the Court's aversion to prophylactic rules to protect individual rights. Under existing law, evidence that comes into plain view during an otherwise lawful search may be seized and offered at trial regardless of whether it was what the police expected to find or whether they came upon it unexpectedly. ${ }^{137}$ Exclusion of such evidence is limited to situations where the evidence comes into plain view as the result of some predicate police illegality, in which case the cost of excluding probative evidence is outweighed by the deterrent effect that exclusion will have on future police misconduct. Following this line of reasoning, if the proposed threat-based test for reasonable suspicion is adopted, any contraband police uncover while acting within the scope of a protective search would be subject to plain view seizure and admission. However, as suggested above, a protective search based on the type of nonpredictive anonymous tip deemed objectively deficient in J.L. undermines the efficacy of this normal exclusionary rule equation. In such situations, there is no meaningful objective basis for a reviewing court to critique the reasonableness of the police judgment to conduct the search. Distinguishing good faith from bad faith when contraband other than that related to the threat that triggered the search is uncovered and seized therefore becomes almost impossible. Instead, it is the nature of

136. See Florida v. J.L., 529 U.S. 266, 271-72 (2000).

137. See Horton v. California, 496 U.S. 128, 141-42 (1990). The Court stated: As we have already suggested, by hypothesis the seizure of an object in plain view does not involve an intrusion on privacy. If the interest in privacy has been invaded, the violation must have occurred before the object came into plain view and there is no need for an inadvertence limitation on seizures to condemn it.

Id. (footnote omitted). 
the potential risk to the public and police that renders reliance on such minimal evidence objectively reasonable.

This risk-driven reasonableness inquiry, combined with the risk that the search was the result of some illicit conduct by either the informant or the police, justifies a post-hoc assessment of reasonableness. Accordingly, unless the evidence seized indicates the tip was in fact reliable, admissibility in the prosecution case-in-chief would be unjustified. This approach would strike a fair balance between a reasonable protective police response to a tip that cannot be pre-validated as reliable, and the legitimate interest of the target of the allegedly protective search to be shielded from the inherent risk associated with being subjected to a search based on a tip with no objective indicia of reliability, even a protective search. This is exactly the risk that led the Court to unanimously conclude the search in J.L. was unreasonable. Where the reasonableness of the police response is validated by discovery of evidence related to the tip, however, that evidence and any other evidence discovered in plain view will be admissible because it validates the tip's reliability. When only unrelated evidence is discovered, that evidence will be inadmissible. This limited-use approach will send a clear message to police that subterfuge in order to seize evidence otherwise beyond their reach is futile. Furthermore, it will not require assessment of police motives, an aspect of reasonableness analysis the Court has eschewed. ${ }^{138}$ Thus, even where police assume the tip is valid, the rule would protect the citizen not only from potential police subterfuge, but also from the unscrupulous or overly paranoid neighbor who fabricates such a tip.

It must, however, be noted that because admissibility of discovered evidence resulting from such a protective search would be dictated by the nature of the evidence, this limited-use proposal would prohibit the introduction of evidence even in the absence of police misconduct. In other words, it would be irrelevant whether the tip proved unreliable as the result of a lying or misinformed informant, or deliberate police abuse of the protective search exception. However, requiring exclusion as a

138. See, e.g., Whren v. United States, 517 U.S. 806, 806 (1996) ("Subjective intentions play no role in ordinary, probable-cause Fourth Amendment analysis."); United States v. Robinson, 414 U.S. 218, 236 (1973). In Robinson, the Court stated:

[I] $t$ is of no moment that [the police officer who conducted the search] did not indicate any subjective fear of the respondent or that he did not himself suspect that respondent was armed. Having in the course of a lawful search come upon the crumpled package of cigarettes, he was entitled to inspect it; and when his inspection revealed the heroin capsules, he was entitled to seize them as fruits, instrumentalities, or contraband probative of criminal conduct.

Robinson, 414 U.S. at 236 (footnote omitted) (citations omitted) (internal quotation marks omitted). 
means to limit police search authority even in the absence of police misconduct was acknowledged in J.L. as legitimate to protect the citizen not only from such misconduct, but also from unscrupulous informants. Indeed, the primary concern invoked by the Court in that case in relation to reliance on a non-predictive anonymous tip was not police misconduct, but the lying informant. ${ }^{139}$ Nonetheless, because the Court has consistently emphasized the link between exclusion of tangible evidence and deterrence of police misconduct, ${ }^{140}$ decoupling deterrence of police misconduct from a rule of evidentiary exclusion is difficult to justify.

\section{B. The Military Exclusionary Approach}

One solution to the over-breadth of the first option is to consider an alternate approach that links exclusion to an inference of police misconduct in the form of subterfuge. As noted above, military criminal practice offers a useful model for this more limited exclusionary approach. ${ }^{141}$ Evidence admissibility in courts-martial generally mirrors that of federal criminal trials. ${ }^{142}$ Like all citizens, the Fourth Amendment safeguards against unreasonable search and seizure protect members of the armed forces, even when a commander orders the search or seizure. Unlike the normal search and seizure context, however, what qualifies as a reasonable expectation of privacy in the military community is sometimes different than in the civilian community, and the process for assessing probable cause and authorizing evidentiary searches is also different. ${ }^{143}$

These processes are established by the Military Rules of Evidence (MREs). In many respects, the MREs are almost identical to the Federal Rules of Evidence (FREs). However, unlike the FREs, the MREs include a section establishing search and seizure authority, authorization

139. See J.L., 529 U.S. at 270.

140. See, e.g., Herring v. United States, 555 U.S. 135, 143 (2009) ("The extent to which the exclusionary rule is justified by . . . deterrence principles varies with the culpability of the law enforcement conduct."); United States v. Leon, 468 U.S. 897, 912 13 (1984) ("The propriety of retroactive application of a newly announced Fourth Amendment principle, moreover, has been assessed largely in terms of the contribution retroactivity might make to the deterrence of police misconduct.") (citations omitted).

141. See supra note 135 and accompanying text.

142. Compare MIL. R. EVID. 401-03, with FED. R. EVID. 401-03.

143. See South Dakota v. Opperman, 428 U.S. 364,370 n.5 (1976) ("The standard of probable cause is peculiarly related to criminal investigations, not routine, noncriminal procedures. The probable-cause approach is unhelpful when analysis centers upon the reasonableness of routine administrative caretaking functions, particularly when no claim is made that the protective procedures are a subterfuge for criminal investigations.") (citations omitted). 
process, and evidentiary admissibility rules. ${ }^{144}$ Just as in the civilian context, any intrusion into a reasonable expectation of privacy for the purpose of investigating suspicion of crime and gathering evidence must be based on probable cause. ${ }^{145}$ Authorization is also normally required, and may be granted by a commander, a military magistrate, or a federal judge. ${ }^{146}$ All established exceptions to the warrant and probable cause requirement that apply in the civilian context also apply in the military context.

Perhaps the most unique aspect of military search and seizure law is MRE 313, which addresses the admissibility of evidence seized during the course of an inspection. According to MRE 313(b):

An "inspection" is an examination of the whole or part of a unit, organization, installation, vessel, aircraft, or vehicle, including an examination conducted at entrance and exit points, conducted as an incident of command the primary purpose of which is to determine and to ensure the security, military fitness, or good order and discipline of the unit, organization, installation, vessel, aircraft, or vehicle. $^{147}$

MRE 313(a) provides that any evidence obtained during an inspection conducted in accordance with the rule is admissible at trial. ${ }^{148}$

Inspections are unsurprisingly a ubiquitous aspect of military life. Commanders use inspections constantly to ensure the health, welfare, and fitness for duty of their units. ${ }^{149}$ Inspections range from assessing the cleanliness of a soldier's quarters to conducting a urinalysis to ensure that soldiers are not using illegal narcotics and are therefore fit for duty. However, it is equally obvious that the broad authority for lawful use of inspections is an invitation for using inspections as a subterfuge to discover evidence of a crime when the normal search and seizure requirements cannot be satisfied. For example, assume a unit commander hears a rumor that a soldier in her unit is selling drugs to other soldiers out of his barracks room. The commander, vested with statutory authority to grant a search authorization based on probable cause, could conduct an investigation in an attempt to establish the requisite probable cause to order a search of the suspect's room. However, what if the commander realizes that she will be unable to meet that cause requirement? Because she is also vested with the authority to

144. See MIL. R. EvID. 311.

145. See id. 313(c)(3), 315.

146. See id. 315(d).

147. Id. 313(b).

148. See id. 313(a).

149. See MIL. R. EVID. 313(b)(1). 
order a health and welfare inspection of the barracks, she might very well do so in hopes of uncovering contraband in the suspected soldier's barracks room. If that evidence is discovered, should it be admissible at trial?

MRE 313(b)(2) contemplates this risk of subterfuge, and provides: "An examination made for the primary purpose of obtaining evidence for use in a trial by court-martial or in other disciplinary proceedings is not an inspection within the meaning of this rule." 150 Accordingly, the evidence will not be admissible as the fruits of an inspection. But what if the commander simply asserts that her primary purpose was legitimate and not to discover evidence for use at trial? MRE 313(b)(3)(B) also addresses this risk, and provides:

The prosecution must prove by clear and convincing evidence that the examination was an inspection within the meaning of this rule if a purpose of an examination is to locate weapons or contraband, and if: (i) the examination was directed immediately following a report of a specific offense in the unit, organization, installation, vessel, aircraft, or vehicle and was not previously scheduled; (ii) specific individuals are selected for examination; or (iii) persons examined are subjected to substantially different intrusions during the same examination. ${ }^{151}$

This rule of evidence provides an effective means by which a defendant may raise the inference of invalid use of inspection authority. If evidence indicates the inspection was ordered in response to suspicion of criminal activity, or that the manner of inspection execution suggests there was a specific target, a presumption of inadmissibility is triggered, requiring the government to rebut the presumption by clear and convincing evidence.

Applied to the terrorist tip scenario analyzed in this Article, a rule analogous to MRE 313(b) would trigger a presumption of inadmissibility for all evidence found in an expanded Terry protective search, unless the prosecution could show clear and convincing evidence that the search was based on reasonable suspicion as understood in the expanded sense discussed above. A look at the difference between the civilian criminal context and the military paradigm, however, highlights several disconnects that could impact the effectiveness of the rule directly applied. In the military inspection context, the combined effect of the small and closely connected relationship between commanders and members of their units, and the professional ethos of integrity, facilitates defense efforts to identify subterfuge. First, it is often common for other members of the defendant's unit to be aware that the command had

150. Id. 313(b)(2).

151. Id. 313(b)(3)(B). 
focused a generalized suspicion on the defendant. News travels fast in a military unit, and when the commander decides that a subordinate is probably involved in misconduct-in the subterfuge inspection context, this will frequently be a suspicion that the subordinate is using illegal narcotics-the "he's a dirtbag" message is often transmitted to other members of the unit either explicitly or implicitly. Thus, when the defense counsel searches for evidence of subterfuge, it often comes from other subordinates who share their own interactions with the commander or other members of the leadership team. Identifying subterfuge is also facilitated by the military professional ethos of integrity. Commanders confronted with direct questions regarding when and why they suspected a subordinate, and why they ordered an inspection, will normally respond with candor. Of course, this is not always the case. However, the culture of integrity within the military will inevitably impact the efficacy of defense efforts to identify subterfuge.

The first of these factors is simply inapposite to the anonymous car bomb tip context. Unlike the soldier targeted for an invalid inspection, it will be almost impossible for the subject of a subterfuge police search to find others who will attest to the ulterior police motives. Nor is the discovery process likely to enhance the probability of finding such witnesses. If subterfuge is in fact the motive for a vehicle search, it is counterintuitive that police would document such an illicit motive. The second factor-a cultural ethos of integrity and candor on the part of those responsible for the government action-may very well be equally significant in this context. It is likely, however, that members of the civilian defense bar would be skeptical that police officers engaged in such searches would candidly admit a subterfuge motive, especially when the search uncovers highly incriminating evidence and they will understand that the consequence of candor is suppression. Or, perhaps in the military context the first factor (which is inapplicable in the police search context) influences the ultimate candor of the commander confronted with the subterfuge allegation. In other words, the commander will be much more reticent about denying subterfuge if she suspects that other subordinates may have already alerted the defense counsel to prior statements or conduct that suggest just such a motive. Extracting the influence of this factor from the equation in the civilian police context must inevitably undermine potential efforts of a defense counsel to expose a subterfuge motive.

Adopting a similar approach as a limitation on the use of evidence seized during a car bomb protective search would protect individuals from the consequence of subterfuge by the police. Perhaps more importantly, it would link exclusion to an inference of police misconduct, thereby aligning the limitation with the existing police deterrence 
rationale police for the exclusionary rule. However, only the first of the three adverse inference triggers in MRE 313(b) would logically extend to the protective search context. Because such searches would be based on individualized suspicion, there would be no way to assess legitimacy by comparison to other search targets, as in the case of an inspection. The result of these differences is that some alternate approach for triggering the subterfuge presumption is necessary.

The most logical solution for a limitation based on MRE 313 would be a more hybrid approach: trigger a presumption of inadmissibility for any evidence unrelated to the alleged terrorist activity, rather than for all evidence. This is a clear and objective indication that the search may have been conducted after police already suspected the defendant for an unrelated offense. This subterfuge inference would not trigger an absolute exclusionary rule, but would instead require exclusion unless the prosecution can prove by clear and convincing evidence that the search was a genuine response to an imminent threat of a bomb attack, and not a subterfuge.

This approach is certainly less protective against subterfuge or the lying informant than an absolute exclusion of any evidence unrelated to the alleged terrorist threat triggering the search-the first limitation option above. It also relieves the defendant of the initial burden to raise the inference of subterfuge. This certainly runs counter to normal suppression practice that requires defendants to provide some evidence of police misconduct in order to trigger exclusion of evidence. The fact that it is often difficult to discover such evidence has never been considered a justification for altering the basic principle that exclusion requires evidence of some unlawful police conduct. However, as noted above, in this very unique context, imposing such a burden on the defendant may functionally nullify any effort to limit the use of alleged terrorism tips as a subterfuge to conduct an otherwise unreasonable search or seizure.

This balance between an absolute exclusionary rule and the existing plain view doctrine strikes a fair balance between protecting individuals from subterfuge search, and permitting the government to introduce evidence--whether related to terrorism or not-seized as the result of a truly reasonable search. Is it possible that this will permit the government to admit evidence seized during a protective search that was in fact used as a subterfuge? The answer is yes, but this is no different than any other evidentiary suppression issue. Ultimately, the efficacy of even this rule to protect citizens from an unjustified invocation of an expanded Terry response authority to car bomb threats will be, as in any other invocation of an exclusionary rule, contingent on the adversarial process to establish the requirements for exclusion. Ideally, the risk of 
such exposure itself will deter police from engaging in subterfuge searches, a risk that will increase each time police assert the justification and engage in searches that lead to the seizure of unrelated contraband.

\section{CONCLUSION}

"First responder" is a term that will increasingly define the U.S. counter-terrorism effort. Indeed, much criticism has been leveled at the government for its decision to rely on military power as a first response to the threat of terrorism. Nowhere is that criticism more intense than within the domestic realm. Accordingly, local law enforcement has and will continue to be viewed as the first line of defense against the threat of terrorism. The tactics associated with that threat continue to evolve from those associated with highly organized transnational terrorist groups like al-Qaeda seeking to conduct large-scale attacks, to those of the lone-wolf self-radicalized operative. As a result, the demands placed on local law enforcement to respond to alleged terrorist plots continue to increase. Added to this equation is the reality that improvised explosive devices will likely continue to be the weapon of choice for any terrorist seeking to inflict large numbers of casualties with minimal effort, sophistication, and cost. Easily assembled and employed, and difficult to detect, the use of such devices has come to define contemporary terrorist tactics. Whether in the form of a suicide bomber or a stationary weaponized object such as a car bomb, terrorist use of improvised explosive devices presents a genuine threat to public safety.

Uncovering plots to employ car bombs will therefore be a major focus of law enforcement counter-terrorism efforts. To date, these efforts have been remarkably successful. This has been in large measure the result of law enforcement infiltration of terrorist networks and/or terrorist chat groups, enabling effective investigations early in the bomber's planning cycle. As the nature of this threat becomes increasingly individual and less organized in nature, the efficacy of this investigative approach will necessarily decline. Instead of infiltration tactics, effective detection and prevention of such attacks will likely become increasingly dependent on informant tips.

Ideally, such tips will trigger investigative efforts that produce independent probable cause to justify searches and seizures of terrorist related contraband in time to avert a catastrophic attack. Even the police response to the terrorist attempt to detonate an IED in Times Square demonstrates that in the right circumstances, an anonymous tip can trigger an investigation that produces probable cause and rapid police response that protects the public. However, in that case, police were genuinely fortunate that the information that produced probable cause 
was readily observable from outside the vehicle that had been weaponized. What is the reasonable response if the tip does not lead to such an observation?

Application of existing Fourth Amendment standards of reasonableness results in an unsatisfactory answer: police must continue to investigate a tip of an imminent terrorist bomb attack until they establish some objective indicia of reliability. Even then, existing Fourth Amendment standards would permit a protective search of an individual suspected of carrying a suicide bomb, but not necessarily the interior search of an automobile suspected of having been weaponized. Both the limitation on the initial response and on the scope of a responsive search seem unreasonable in this context. Instead, whether responding to a tip of a suicide bomber or a car bomb, the reasonable response seems clear: seize the individual or vehicle and conduct a narrowly tailored protective search to confirm or deny the threat. Any other response will subject the public to a grave danger, and if police hesitate to respond to the tip with the result of widespread casualties, that hesitation will almost certainly be condemned as unreasonable.

Permitting a protective search in response to an anonymous nonpredictive tip of imminent terrorist attack therefore seems consistent with the underlying rationale of the Terry doctrine. A unanimous Supreme Court suggested as much in Florida v. J.L. However, because extending the Terry protective seizure and search to this context decouples police action from any meaningful objective indicia of reliability, a terrorist threat exception to the normal test for reasonable suspicion creates a genuine risk of subterfuge. The response to this risk is not rejection of the terrorist threat exception; it is to adopt a limited-use doctrine for evidence seized as the result of invoking the exception.

Establishing either a conclusive or presumptive rule of inadmissibility for evidence seized as the result of a protective search that is unrelated to the threat that triggered the search will ensure an appropriate balance between public safety and individual liberty. A true limited-use rule - one that limits evidence available for use at trial only to that related to the threat that triggered the search-will have the greatest deterrent effect on potential police subterfuge. Perhaps more importantly, it will protect the target of the search from ulterior motives of the informant, even where police act in good faith. Such an approach may be inconsistent with the traditional requirement that exclusion be linked to police misconduct. However, it is responsive to the concerns raised by the Court in Florida v. J.L. that endorsing a threat-specific reduction in the objective component of reasonable suspicion will subject individuals to harassment by other members of the community, namely the prevaricating informant. 
The alternative would be to adopt a rule similar to Military Rule of Evidence 313(b), which protects service-members from the risk of command use of inspection authority as a subterfuge to avoid compliance with the normal individualized suspicion requirement of the Fourth Amendment. This rule would be triggered by offering as evidence against a defendant contraband seized during the course of a protective search unrelated to the threat that led to the search. Because of the lack of relation between the alleged justification for the search and the evidence, a presumption of inadmissibility would apply to such evidence. At that point, admissibility would be permitted only when the prosecution is able to rebut the presumption of subterfuge with clear and convincing evidence that the search was a legitimate invocation of the Terry protective doctrine.

Ultimately, waiting for the next major terrorist attack to occur is not the ideal time to address this twilight zone that lies between existing Fourth Amendment jurisprudence, the evolving nature of the terrorist threat to society, and law enforcement investigative techniques. Instead, both Congress and state legislatures should consider endorsing this terrorism threat protective search approach by statute, thereby triggering the inevitable judicial scrutiny that will ensue. The alternative is to subject police to a dilemma between public safety and subsequent evidence admissibility, a dilemma that in the context of a terrorist tip will almost certainly be resolved in favor of safety. Police should be confident that in such situations their conduct is not only pragmatically reasonable, but also legally reasonable. 
